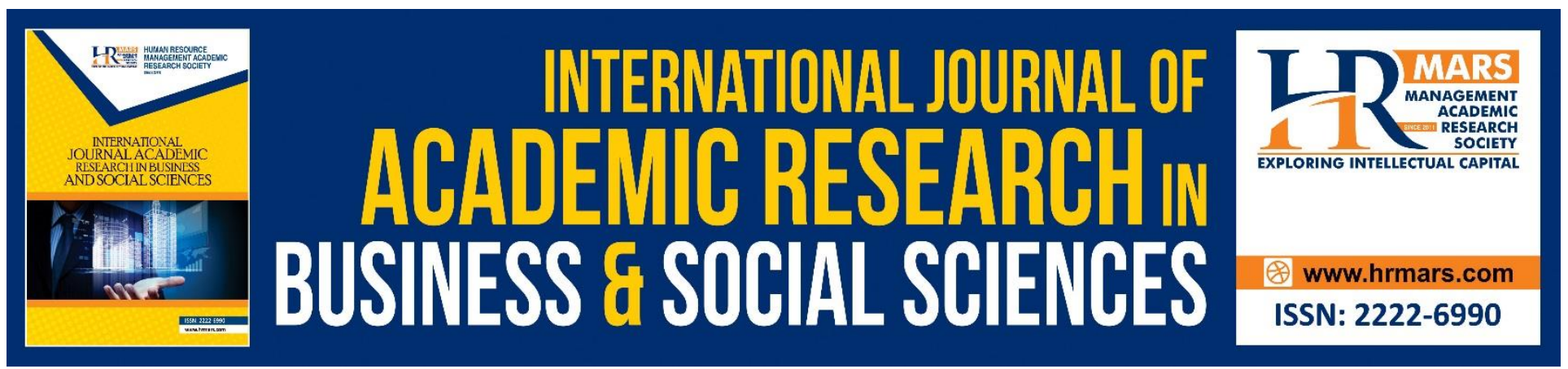

\title{
Virtual Training Effectiveness among Disabled People: A Research Framework
}

\author{
Tetty Ruziyati A Hamid, Nor Wahiza Abdul Wahat, Siti Noormi Alias, Mohd \\ Ashraff Mohd Anuar
}

To Link this Article: http://dx.doi.org/10.6007/IJARBSS/v10-i11/8135

DOI:10.6007/IJARBSS/v10-i11/8135

Received: 03 September 2020, Revised: 26 September 2020, Accepted: 13 October 2020

Published Online: 25 November 2020

In-Text Citation: (Hamid, Abdul Wahat, Alias, \& Anuar, 2020)

To Cite this Article: Hamid, T. R. A., Abdul Wahat, N. W., Alias, S. N., \& Anuar, M. A. M. (2020). Virtual Training Effectiveness among Disabled People: A Research Framework. International Journal of Academic Research in Business and Social Sciences. 10(11), 728-738.

Copyright: (C) 2020 The Author(s)

Published by Human Resource Management Academic Research Society (www.hrmars.com)

This article is published under the Creative Commons Attribution (CC BY 4.0) license. Anyone may reproduce, distribute, translate and create derivative works of this article (for both commercial and non-commercial purposes), subject to full attribution to the original publication and authors. The full terms of this license may be seen at: http://creativecommons.org/licences/by/4.0/legalcode

Vol. 10, No. 11, 2020, Pg. 728 - 738

http://hrmars.com/index.php/pages/detail/IJARBSS

JOURNAL HOMEPAGE

Full Terms \& Conditions of access and use can be found at http://hrmars.com/index.php/pages/detail/publication-ethics 


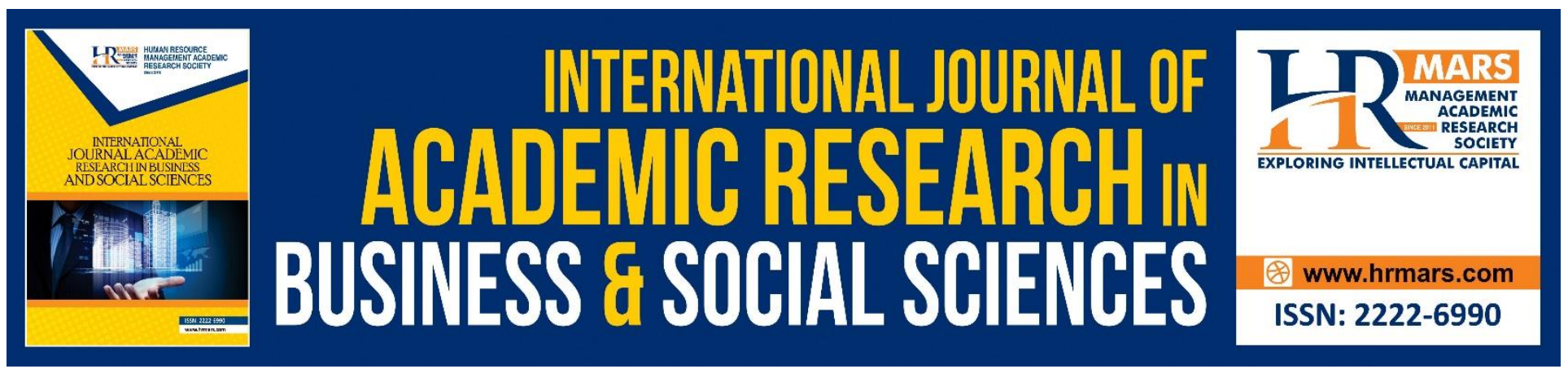

\title{
Virtual Training Effectiveness among Disabled People: A Research Framework
}

\section{Tetty Ruziyati A Hamid, Nor Wahiza Abdul Wahat, Siti Noormi Alias, Mohd Ashraff Mohd Anuar}

Department of Professional Development and Continuing Education, Faculty of Educational Studies

Universiti Putra Malaysia, Malaysia

Email: tettyrah@gmail.com, wahiza@upm.edu.my, sitinoormi@upm.edu.my,

mohdashraff@upm.edu.my

\begin{abstract}
Employees are the most important asset of any organization regardless of their capabilities. Even though the number of disabled people currently employed in Malaysia labour workforce still consider small, their rights for training and development opportunities cannot be ignored. Due to globalization, boundaryless world and current outbreak of Corona Virus (COVID-19), the need for virtual training and development have increased gradually. However, due to the limited number of reported training conducted, therefore, knowledge related to its effectiveness are also inadequate. This review of past studies from 2016-2020 has been conducted to fill in the gap by proposing a framework related to factors influencing training effectiveness among disabled people. Google Scholar has been used as a general searching platform that will direct researchers to scholarly academic electronic databases such as Emerald, Springer Link, and Wiley Online Library. Based on Training Engagement Theory developed by Sitzmann and Weinhardt (2015), this study has proposed a research framework for further investigation. Implications for future research also provided at the end of this article.
\end{abstract}

Keywords: Virtual Training, Training Effectiveness, Employees With Different Abilities, Disabled Employees, Disabled People.

\section{Introduction}

Employees are the most important asset of any organization. Regardless of their disabilities, they can contribute to the performance of organizations (Luu, et al., 2020) particularly when were provided with suitable and ample training and development opportunities. Training, in general is really significant towards physical, social, intellectual, and productivity improvement (Grossman \& Salas, 2011; Ganesh \& Indradevi, 2015). And even, systematic training courses are needed to ensure all employees able to accomplish their job requirements (Armstrong \& Taylor, 2020; Singh, 2016). 
INTERNATIONAL JOURNAL OF ACADEMIC RESEARCH IN BUSINESS AND SOCIAL SCIENCES Vol. 10, No. 11, 2020, E-ISSN: 2222-6990 @ 2020 HRMARS

Employees abilities and skills need to be maintained and improved to prepare the workforce with competitive and challenging business environment (Arguinis \& Kraiger, 2009).

Due to globalization, boundaryless world and current outbreak of Corona Virus (COVID-19), training and development deliveries also changed accordingly. From traditional face-to-face training to virtual training that can be accessed everywhere with the availability of gadget and internet. This shift benefits disabled employees to get continuous training and development opportunities. Among the advantages of virtual training programs to disabled employees include they are not bound to any physical location, and the training content can be reviewed or replayed as many as the trainee wants (Pleasant, Molinari, Dobbs, Meng, \& Hyer, 2020; Kraiger, 2014). A well-developed system that met the need for different type of disabled employees could increase their loyalties toward organizations.

There is a growing demand for virtual training program among disabled employees (e.g., Lindsay, Cagliostro, Leck, Shen, \& Stinson, 2019; Kim, 2015). Nevertheless, the reported studies on virtual training effectiveness is inadequate (Bertram, Moskaliuk, \& Cress, 2015). This review of past studies has been conducted to fill in the gap by proposing a framework related to factors influencing virtual training effectiveness among disabled people. This paper has been arranged according to the following sequence; review of literature, methodology, findings and discussions, implications and recommendations.

\section{Literature Review}

Defining Virtual Training

According to Training Industry (2020), virtual training refers to training done in a virtual or simulated environment, or when the learner and the instructor are in separate locations. It involves a wide range of desktop applications that run on standard computers. Moskaliuk, Bertram, and Cress (2013) added that virtual training allows a three-dimensional representation and two-way communications between trainer and trainees. It provides online training materials and repositories, courses interactions, communications and presentation through technology (Johnson, Hornik, \& Salas, 2008; Allen \& Seaman, 2013).

Virtual training refers to a broad set of application and process such as web-based learning, computer-based training, and digital collaborations (Bondarouk \& Ruël, 2010; Vernadakis, Antoniou, Giannousi, Zetou, \& Kioumourtzoglou, 2011) or training deliveries through computer technology either using intranet or internet. It could be implemented anywhere at any time (Welsh, Wanberg, Brown, \& Simmering, 2003; Zhang \& Nunamaker, 2003). It can also be in the form of virtual reality (VR) which refers to a type of computer-generated simulation that enables a trainee to interact within an artificial three-dimensional environment using electronic devices (i.e., goggles with a screen or gloves fitted with sensors) (Mitchell, 2020). Through this simulated artificial environment, the trainee can have a realistic-feeling experience. In a healthcare setting, this VR technology has been used widely as a visualization for diagnosis and rehabilitation purposes among physicians (Kuhlen \& Dohle, 1995).

This study, however, adapted a definition of e-learning given by Tavangarian, Leypold, Nölting, Röser, and Voigt (2004) into this context of the study. Tavangarian et al. (2004, p. 274) state that e-learning 
INTERNATIONAL JOURNAL OF ACADEMIC RESEARCH IN BUSINESS AND SOCIAL SCIENCES

Vol. 10, No. 11, 2020, E-ISSN: 2222-6990 @ 2020 HRMARS

refers to "all forms of electronically supported learning and teaching, which are procedural in character and aim to affect the construction of knowledge concerning individual experience, practice and knowledge of the learner."

\section{Virtual Training Effectiveness among Disabled People}

In general, training effectiveness focuses on an overall learning system that highlights the macro outcome of a training (Alvarez, Salas, \& Garofano, 2004). Sitzmann and Weinhardt (2015, p. 2) define training effectiveness as "the extent to which training produced the intended results." Every training programs was conducted to improve participants' or employees' knowledge, behaviour, skills, and attitude. It depends mostly on individual characteristics, training (e.g., training content), and organization (Alvarez et al., 2004). Training effectiveness does not rely on the number of training conducted, but more on how much productivity improvement recorded. Therefore, a training program is said to be useful if the elements of knowledge, behaviour, skills, and attitude learned during the training session were successfully transferred to the workplace. Virtual training conducted among people with different types of disabilities requires more flexibilities and concern compared to traditional face-to-face training.

\section{Training Engagement Theory}

Training Engagement Theory has supported this study that is related to factors influencing virtual training effectiveness among disabled people by Sitzmann and Weinhardt (2015). Training Engagement Theory by Sitzmann and Weinhardt (2015) proposed multilevel antecedents of training effectiveness. "Multilevel" in this context refers to the micro level (i.e., individual employee (withinperson) working in a group (between-person) within organization's environment) and macro-level (processes involve to complete a job task). Compared to existing theories which mostly focusing on the static evaluation and ignored the fact that various processes are interconnected to each other resulting in training effectiveness. This theory therefore go beyond the Kirkpatrick (1959) training evaluation (reaction, learning, behaviour and results) (Sitzmann \& Weinhardt, 2015; (Sitzmann \& Weinhardt, 2019)

Training success depends on the interconnection of all processes at a different level in an organizational hierarchy. For example, if training is easily connected to organization's high-level goal, the trainee is likely to have higher intentions to transfer training. This theory asserted that all processes, which occur before (i.e., inclusivity in organizational decision making process), during (i.e, specific needs of virtual training platform), and after (i.e., combination of virtual training with coaching-on-the job) the completion of training should be considered as antecedents of training effectiveness. All these variables can interact with other categories of variables, including trainee characteristics (i.e., level of mindfulness) that may significantly impact training effectiveness (Roehling \& Huang, 2018).

\section{Methodology}

This study is based on extensive reviews of past studies on factors influencing virtual training effectiveness among disabled people, covering international literature available through online databases. Google Scholar has been used as a general searching platform that will direct researchers 
INTERNATIONAL JOURNAL OF ACADEMIC RESEARCH IN BUSINESS AND SOCIAL SCIENCES

Vol. 10, No. 11, 2020, E-ISSN: 2222-6990 @ 2020 HRMARS

to scholarly academic electronic databases such as Emerald, Springer Link, and Wiley Online Library. Aside from using online resources to obtain literature, relevant textbooks that are related to training effectiveness among disabled people are also utilized to support the findings of the past literature further. To ensure the information is recent and relevant, literature gathered (i.e., journals, conference proceedings, books, reports, and websites) are limited for publication in English literature from year 2016 to 2020 only. The literature from electronic databases are filtered according to keywords such as "virtual training effectiveness", "online training effectiveness", "virtual training for disabled people", and "online training for disabled people".

\section{Findings and Discussion}

This section will present the findings of the study related to factors influencing virtual training effectiveness among disabled people.

\section{Factors Influencing Virtual Training Effectiveness among Disabled People}

\section{Specific Needs of Virtual Training Platform}

Types of disability will influence the best tools and methods to be used for virtual training sessions. Virtual training attracts the attention of organizations and training provider due to its potential to solve two key problems which include to optimize human resource potential and to address their specific needs (Ford, Piccolo, \& Ford, 2017). A study conducted by Batanero, de-Marcos, Holvikivi, Hilera, and Otón (2019) found out that the adapted Moodle learning platform by adding content which were non-auditory and non-visual to deaf or blind students and students upload reusable profiles/metadata describing their specific accessibility needs to connect to suitably adjusted content have resulted in significant learning improvement across all groups (i.e., blind (45\%), deaf (46.25\%) and deaf-blind (87.5\%)). Specific needs in this context refer to the development and designs of a virtual platform made fulfils the actual needs of the targeted group (i.e., deaf, blind).

Studies on visually impaired trainees as well as individuals with physical, sensory and intellectual disabilities), have concluded that specifically designed virtual training platform enabled more access and promised a higher tendency of transfer to an actual setting (Flamaropol, et al. , 2018a; Tariq, Rana, and Nawaz (2018); Sobota, et al. (2017); Pouvrasseau, et al. (2017); Flamaropol, et al. (2018). Accordingly, this study proposed that:

Proposition 1: Specific needs of virtual training platform will increase traning effectiveness among disabled people.

\section{Combination of Virtual Training with Coaching-on-the Job}

Researchers used a "Combination of virtual training with coaching-on-the job among disabled people" and "Combination of virtual training with coaching-on-the job among disabled people and training effectiveness" resulted in none relevant articles. Accordingly, researchers have refined the search keywords into more general and omitted the "disabled people" (i.e., Combination of virtual training with coaching-on-the job and training effectiveness). A study conducted by Towson, Taylor, and Tucker (2018) found that participants demonstrated improvement in communication skills after 
INTERNATIONAL JOURNAL OF ACADEMIC RESEARCH IN BUSINESS AND SOCIAL SCIENCES Vol. 10, No. 11, 2020, E-ISSN: 2222-6990 @ 2020 HRMARS

virtual simulation and coaching as intervention. Cheng, et al. (2018) asserted that coaching-on-the job is one of effective strategies to enable disabled people (i.e., physical, sensory and intellectual disabilities) achieve better employment outcomes. Knowledge obtained during the training sessions can be reinforced through direct coaching received from supervisor or mentor. Accordingly, the probaility of transferring knowledge to the workplace setting will be higher. Therefore, this study proposed that:

Proposition 2: Combination of virtual training with coaching-on-the job will increase traning effectiveness among disabled people.

\section{Inclusion in Organizational Change}

Issue related to inclusion in organizational development and change mostly discussed in diversity management studies and workplace disability management (Roberson, Ryan, \& Ragins, 2017). Organizational change refers to efforts targeted towards organizational goal achievement. It can be in either proactive - which is the organization initiate a change according to the current organizational strategy or reactive - which is the organization developed action plan according to featured needs. Involvement of disabled employees in organizations' decision-making process could increase their organizational citizenship and responsibilities. It can trigger the need for change and therefore reduced resistance for change (Gagnon \& Collinson, 2017). As a result, they are more selfmotivated to transfer the knowledge gained during training to their workplace (Suresh \& Dyaram, 2020). Therefore, it is proposed that:

Proposition 3: Inclusion in organizational change will increase traning effectiveness among disabled people.

\section{Moderating Role of Mindfulness}

Mindfulness can be defined as non-judgmental acceptance of the current state of live (Kappen, Karremans, \& Burk, 2019; Ramasubramanian, 2017; Rayan \& Ahmad, 2016; Tan \& Martin, 2016). A few more different definitions given by scholars include "the act of noticing new things, a process that promotes flexible response to the demands of the environment" (Pagnini, Bercovitz, \& Langer, 2016, p. 91), related to "optimism, self-efficacy, and adaptability" (Malow \& Austin, 2016, p. 81), and "paying attention to what's happening in the present moment in the present mind, body and external environment, with an attitude of curiosity and kindness (MAPG, 2015, p. 5 as cited in Porter, Bramham, \& Thomas, 2017, p. 199).

Whilst not many studies has been conducted, researchers want to highlight the potential moderating effect of mindfulness due to a) a vast researchers have proposed the applicability of mindfulness at workplace (e.g., Krick \& Felfe, 2020; Ramaci, et al., 2020; Wei, Fenfen , \& Chen, 2020; Charoensukmongkol, 2016), and b) due to its attribute, which reflects individual self-awareness to respond to the demands of the environment. This study, therefore, proposed that:

Proposition 4: Mindfulness moderates the relationships between all the proposed independent variables and training effectiveness among disabled people. 
INTERNATIONAL JOURNAL OF ACADEMIC RESEARCH IN BUSINESS AND SOCIAL SCIENCES Vol. 10, No. 11, 2020, E-ISSN: 2222-6990 @ 2020 HRMARS

Figure 1 below illustrates the proposed research framework of this study.

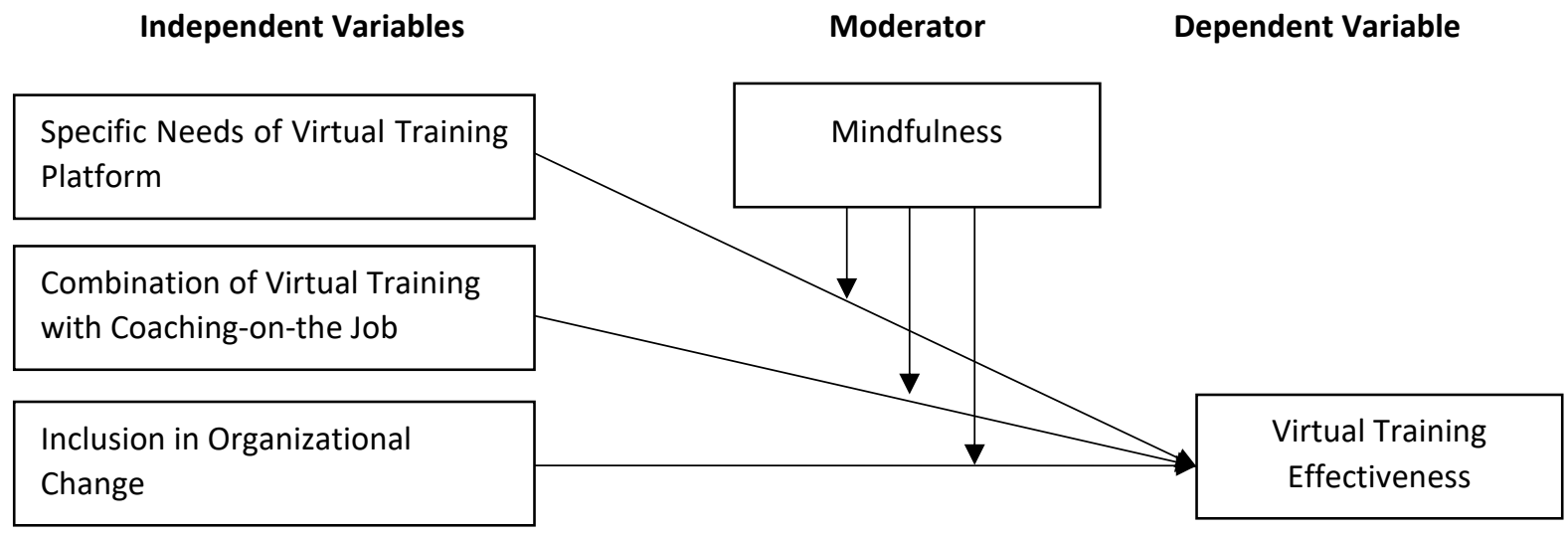

Figure 1: Proposed Research Framework

\section{Implications}

Virtual training is necessary as an ongoing organizational strategy to remain competitive in the marketplace. With all the limitations faced by organizations and businesses during COVID-19, virtual training seems to be a must, regardless of employees abilities. This study, which is related to identifying factors influencing virtual training effectiveness, has identified the potential moderating effect of mindfulness based on Training Engagement Theory. Since this study solely supported by literature, empirical based studies through quantitative research should be conducted in future to confirm the proposed model. In addition, a qualitative study should possibly be conducted to explore the processes involve and the interconnectedness between them to produce a more holistic training effectiveness model.

Since its establishment in 2015, there are still limited empirical studies have been conducted to confirmed the Training Engagement Theory as most researchers and scholars still consider Kirkpatrick (1959), Baldwin \& Ford (1988), and Baldwin, Ford, and Blume (2012) as the pioneer that provide the foundation of training evaluation measures. This study therefore, may attract more studies within the area to further expand the theory.

Training effectiveness does not solely depend on individual trainee responsibility. The outcomes of any training (i.e., knowledge, skill, and attitude) can fully be transferred through operational support at all levels in an organization before attending the training. During the sessions, the trainer and the training provider should develop appropriate platform accordingly to the targeted audience.

\section{References}

Schmeeckle, J. M. (2003). Online training: An evaluation of the effectiveness and efficiency of training law enforcement personnel over the internet. Journal of Science Education and Technology, 12(3), 205-260. 
INTERNATIONAL JOURNAL OF ACADEMIC RESEARCH IN BUSINESS AND SOCIAL SCIENCES

Vol. 10, No. 11, 2020, E-ISSN: 2222-6990 @ 2020 HRMARS

Brookfield, S. D. (1984). Self-directed adult learning: A critical paradigm. Adult Education Quarterly, 35(2), 50-71.

Park, J.-H., \& Wentling, T. (2007). Factors associated with transfer of training in workplace e-learning. Journal of Workplace Learning, 19(5), 311-329. doi:10.1108/13665620710757860

Rowold, J. (2007). Individual influences on knowledge acquisition in a call center training context in Germany. International Journal of Training and Development, 11, 21-34. doi:DOI: 10.1111/j.1468-2419.2007.00267.x

Luu, T. T., Rowley, C., Dinh, C. K., Qian, D., Masli, E., \& Hanh, Q. L. (2020). Fostering well-being among public employees with disabilities: The Roles of disability-inclusive human resource practices, job resources, and public service motivation. Review of Public Personnel Administration, 1-31.

Grossman, R., \& Salas, E. (2011). The transfer of training: What really matters. International Journal of Training and Development, 15(2), 103-120.

Ganesh, M., \& Indradevi, R. (2015). Importance and effectiveness of training and development. Mediterranean Journal of Social Sciences, 6(1), 334-338.

Lindsay, S., Cagliostro, E., Leck, J., Shen, W., \& Stinson, J. (2019). Employers' perspectives of including young people with disabilities in the workforce, disability disclosure and providing accommodations. Journal of Vocational Rehabilitation, 50, 141-156.

Kim, M.-j. (2015). Research trends in rehabilitation program for disabled applying virtual reality technology in Korea. Journal of Digital Convergence, 13(2), 381-391.

Bertram, J., Moskaliuk, J., \& Cress, U. (2015). Virtual training: Making reality work? Computers in Human Behavior, 43, 284-292.

Darwish, S., Ahmed, U., \& Pahi, M. H. (2020). Innovative Work Behavior During COVID-19 for Medical Representative in the Pharmaceutical Industry: Test of a Moderation Model in Bahrain. International Journal of Pharmaceutical Research. 12(4), 1927-

1934. doi.org/10.31838/ijpr/2020.12.04.277

Training Industry. (2020). Virtual training. Retrieved September 2020, from Training Industry: https://trainingindustry.com/glossary/virtual-training/

Moskaliuk, J., Bertram, J., \& Cress, U. (2013). Training in virtual environments: Putting theory into practice. Ergonomics, 56(2), 195-204.

Moher, D., Liberati, A., Tetzlaff, J., \& Altman, D. (2009). Preferred Reporting Items for Systematic Reviews and Meta-Analyses: The PRISMA Statement. The PRISMA Group.

Sitzmann, T., \& Weinhardt, J. M. (2015). Training engagement theory: A multilevel perspective on the effectiveness of work-related training. Journal of Management, 4(2), 732-756.

Tavangarian, D., Leypold, M. E., Nölting, K., Röser, M., \& Voigt, D. (2004). Is e-Learning the solution for individual learning? Electronic Journal of e-Learning, 2(2), 273-280.

Batanero, C., de-Marcos, L., Holvikivi, J., Hilera, J. R., \& Otón, S. (2019). Effects of new supportive technologies for blind and deaf engineering students in online learning. EEE Transactions on Education, 62(4), 270-277.

Armstrong, M., \& Taylor, S. (2020). Armstrong's Handbook of Human Resource Management Practice (15th Revised edition). London, United Kingdom: Kogan Page Ltd.

Singh, S. (2016). Impact and effectiveness of corporate training programs through industry-academia tie-ups. Journal of Commerce and Management Thought, 7(2), 309-319. 
INTERNATIONAL JOURNAL OF ACADEMIC RESEARCH IN BUSINESS AND SOCIAL SCIENCES

Vol. 10, No. 11, 2020, E-ISSN: 2222-6990 @ 2020 HRMARS

Ford, R. C., Piccolo, R. F., \& Ford, L. R. (2017). Strategies for building effective virtual teams: Trust is key. Business Horizons, 60(1), 25-34.

Pleasant, M., Molinari, V., Dobbs, D., Meng, H., \& Hyer, K. (2020). Effectiveness of online dementia caregivers training programs: A systematic review. Geriatric Nursing, doi: https://doi.org/10.1016/j.gerinurse.2020.07.004.

Kraiger, K. (2014). Looking back and looking forward: Trends in training and development research. Human Resource Development Quarterly, 25(4), 401-408.

Johnson, R. D., Hornik, S., \& Salas, E. (2008). An empirical examination of factors contributing to the creation of successful e-learning environments. International Journal of Human-Computer Studies, 66(5), 356-369.

Allen, I. E., \& Seaman, J. (2013). Changing Course: Ten Years of Tracking Online Education in the United States. Pearson.

Bondarouk, T., \& Ruël, H. (2010). Dynamics of e-learning: Theoretical and practical perspectives. International Journal of Training and Development, 14(3), 149-154.

Vernadakis, N., Antoniou, P., Giannousi, M., Zetou, E., \& Kioumourtzoglou, E. (2011). Comparing hybrid learning with traditional approaches on learning the Microsoft Office Power Point 2003 program in tertiary education. Computers \& Education, 56(1), 188-199.

Welsh, E. T., Wanberg, C. R., Brown, K. G., \& Simmering, M. J. (2003). E-learning: Emerging uses, empirical results and future directions. International Journal of Training and Development, 7(4), 245-258.

Zhang, D., \& Nunamaker, J. F. (2003). Powering e-learning in the new millennium: An overview of elearning and enabling technology. Information Systems Frontiers, 5(2), 207-218.

Alvarez, K., Salas, E., \& Garofano, C. M. (2004). An integrated model of training evaluation and effectiveness. Human Resource Development Review, 3(4), 385-416.

Mitchell, C. (2020). Virtual Reality. Retrieved November 2020, from Investopedia: https://www.investopedia.com/terms/v/virtual-reality.asp

Kuhlen, T., \& Dohle, C. (1995). Virtual reality for physically disabled people. Computers in Biology and Medicine, 25(2), 205-211.

Flamaropol, D., Moldoveanu, A., Moldoveanu, F., Dascalu, M.-I., Stanica, I., \& Negoi, I. (2018). User behavior analytics in virtual training environments for sensory substitution devices. Zooming Innovation in Consumer Technologies Conference (ZINC), 30-31 May 2018 (pp. 22-66). Novi Sad, Serbia: Institute of Electrical and Electronics Engineers (IEEE).

Sobota, B., Kore, S., Jacho, L., Pastornicky, P., Hudak, M., \& Sivy, M. (2017). Virtual-reality technologies and smart environments in the process of disabled people education. 201715 th International Conference on Emerging eLearning Technologies and Applications (ICETA), 26 27 Oct. 2017 (pp. 1-6). Stary Smokovec, Slovakia: Institute of Electrical and Electronics Engineers.

Tariq, A., Rana, T., \& Nawaz, M. (2018). Virtual reality for disabled people: A survey. 2018 12th International Conference on Open Source Systems and Technologies (ICOSST), 19-21 Dec. 2018 (pp. 17-21). Lahore, Pakistan, Pakistan: Institute of Electrical and Electronics Engineers.

Pouvrasseau, F., Monacelli, E., Charles, S., Schmid, A., Goncalves, F., Leyrat, P.-A., . . Malafosse, B. (2017). Discussion about functionalities of the Virtual Fauteuil simulator for wheelchair 
INTERNATIONAL JOURNAL OF ACADEMIC RESEARCH IN BUSINESS AND SOCIAL SCIENCES

Vol. 10, No. 11, 2020, E-ISSN: 2222-6990 @ 2020 HRMARS

training environment. 2017 International Conference on Virtual Rehabilitation (ICVR), 19-22 June 2017 (pp. 1-7). Montreal, QC, Canada: Institute of Electrical and Electronics Engineers.

Flamaropol, D., Moldoveanu, A., Moldoveanu, F., Dascalu, M.-I., Stanica, I., \& Negoi, I. (2018). User behavior analytics in virtual training environments for sensory substitution devices. 2018 Zooming Innovation in Consumer Technologies Conference (ZINC), 30-31 May 2018 (pp. 2226). Novi Sad, Serbia: Institute of Electrical and Electronics Engineers.

Towson, J. A., Taylor, M. S., \& Tucker, J. (2018). Impact of virtual simulation and coaching on the interpersonal collaborative communication skills of speech-language pathology students: $A$ pilot study. Teaching and Learning in Communication Sciences \& Disorders, 2(2), 1-24.

Cheng, C., Oakman, J., Bigby, C., Fossey, E., Cavanagh, J., Meacham, H., \& Bartram, T. (2018). What constitutes effective support in obtaining and maintaining employment for individuals with intellectual disability? A scoping review. Journal of Intellectual \& Developmental Disability, 43(3), 317-327.

Blume, B. D., Ford, J. K., Surface, E. A., \& Olenick, J. (2019). A dynamic model of training transfer. Human Resource Management Review, 29(2), 270-283.

Roberson, Q., Ryan, A., \& Ragins, B. (2017). The evolution and future of diversity at work. Journal of Applied Psychology, 102(3), 483-499.

Gagnon, S., \& Collinson, D. (2017). Resistance through Difference: The Co-Constitution of Dissent and Inclusion. Organization Studies, 38(9), 1253-1276.

Suresh, V., \& Dyaram, L. (2020). Towards a confluence: Disability inclusion and organizational change. Journal of Indian Business Research, 1-21. doi: 10.1108/JIBR-03-2019-0068.

Kappen, G., Karremans, J. C., \& Burk, W. J. (2019). Effects of a short online mindfulness intervention on relationship satisfaction and partner acceptance: The moderating role of trait mindfulness. Mindfulness, 10(10), 2186-2199.

Krick, A., \& Felfe, J. (2020). Who benefits from mindfulness? The moderating role of personality and social norms for the effectiveness on psychological and physiological outcomes among police officers. ournal of Occupational Health Psychology, 25(2), 99-112.

Ramaci, T., Rapisarda, V., Bellini, D., Mucci, N., De Giorgio, A., \& Barattucci, M. (2020). Mindfulness as a protective factor for dissatisfaction in HCWs: The moderating role of mindful attention between climate stress and job satisfaction. International Journal of Environmental Research and Public Health, 17(11), 1818-1824.

Charoensukmongkol, P. (2016). Mindful Facebooking: The moderating role of mindfulness on the relationship between social media use intensity at work and burnout. Journal of Health Psychology, 21(9), 1966-1980.

Wei, S., Fenfen , Z., \& Chen, X. (2020). Do stressors stifle or facilitate employees' innovative use of enterprise systems: the moderating role of IT mindfulness. Information Technology \& People, 1-22. doi: https://doi.org/10.1108/ITP-09-2019-0499.

Pagnini, F., Bercovitz, K., \& Langer, E. (2016). Perceived control and mindfulness: Implications for clinical practice. Journal of Psychotherapy Integration, 26(2), 91-102.

Ramasubramanian, S. (2017). Mindfulness, stress coping and everyday resilience among emerging youth in a university setting: A mixed methods approach. International Journal of Adolescence and Youth, 22(3), 308-321. 
INTERNATIONAL JOURNAL OF ACADEMIC RESEARCH IN BUSINESS AND SOCIAL SCIENCES

Vol. 10, No. 11, 2020, E-ISSN: 2222-6990 @ 2020 HRMARS

Rayan, A., \& Ahmad, M. (2016). Mindfulness-based intervention: A culturally adaptable intervention in clinical psychology. Clinical Psychiatry, 2(3), 11-12.

Tan, L. B., \& Martin, G. (2016). Mind full or mindful: A report on mindfulness and psychological health in healthy adolescents. International Journal of Adolescence and Youth, 21(1), 64-74.

Malow, M. S., \& Austin, V. L. (2016). Mindfulness for students classified with emotional/behavioral disorder. Insights into Learning Disabilities, 13(1), 81-93.

Porter, N., Bramham, J., \& Thomas, M. (2017). Mindfulness and design: creating spaces for well being. Creative practices for improving health and social inclusion. 5th International Health Humanities Conference (pp. 199-209). Sevilla: Universidad de Sevilla, Vicerrectorado de Investigación.

Roehling, M. V., \& Huang, J. (2018). Sexual harassment training effectiveness: An interdisciplinary review and call for research. The Job Annual Review, 39(2), 134-150.

Kirkpatrick, D. L. (1959). Techniques for evaluation training programs. Journal of the American Society of Training Directors, 13(3), 21-26.

Sitzmann, T., \& Weinhardt, J. M. (2019). Approaching evaluation from a multilevel perspective: A comprehensive analysis of the indicators of training effectiveness. Human Resource Management Review, 29(2), 253-269.

Baldwin, T. T., \& Ford, J. K. (1988). Transfer of training: A review and directions for future research. Personnel Psychology, 41(1), 63-105.

Baldwin, T. T., Ford, J. K., \& Blume, B. D. (2012). Transfer of training 1988-2008: An updated review and agenda for future research. In G. P. Hodgkinson, \& J. K. Ford, nternational Review of Industrial and Organizational Psychology (pp. 41-70). Wiley Online Library. 